\title{
Evidentiary Issues in Philip Morris v Uruguay: The Role of the Framework Convention for Tobacco Control and Lessons for NCD Prevention
}

\author{
Margherita Melillo \\ Max Planck Institute Luxembourg for Procedural Law, Luxembourg, \\ Luxembourg \\ margherita.melillo@eui.eu
}

\begin{abstract}
This article analyses the evidentiary assessment made by the investment Tribunal in the case of Philip Morris with a view to drawing some lessons for the regulation of noncommunicable diseases (NCD) prevention regulations on food, alcohol, and tobacco. After the introduction, the second Section describes why this dispute, like any dispute concerning NCD prevention measures more generally, raised particularly complex evidentiary challenges. The third Section introduces the provisions and features of the 'evidence-based' Framework Convention on Tobacco Control (FCTC) relevant to the dispute. The fourth Section describes the evidentiary assessment made by the Philip Morris Tribunal, highlighting how it relied extensively on the evidence stemming from or related to the FCTC rule in favour of Uruguay. Finally, the last Section draws lessons that the NCD prevention regulation can learn from Philip Morris for respondents in possible future investment disputes.
\end{abstract}

* Research Fellow at the Max Planck Institute Luxembourg for Procedural Law and a $\mathrm{PhD}$ candidate at the European University Institute. I thank all the participants in the 'International Investment Law and NCD Prevention' conference that took place in London on 10-11 May 2018 for the insightful discussions. The guidance of my PhD supervisor, Joanne Scott, has been fundamental in developing the arguments in this paper. Additionally, I thank Amandine Garde, Jure Zrilic, Maria Fanou, and the editors of JWIT for the comments on an earlier draft of this article. The usual disclaimer applies. 


\section{Keywords}

applicable law - evidence - fair and equitable treatment clause (FET) - Framework Convention on Tobacco Control (FCTC) - non-communicable diseases (NCD) proportionality - World Health Organization (WHO)

\section{1 \\ Introduction}

Philip Morris is a paramount case for understanding how international investment law can interact with non-communicable diseases (NCD) prevention measures - that is, regulatory measures taken to address lifestyle risks such as tobacco use, harmful use of alcohol, unhealthy diet, and physical inactivity. ${ }^{1}$ This article focuses on a specific aspect of the Philip Morris dispute, that is, the scientific evidentiary questions that it raised, with a view to drawing some lessons for NCD prevention regulation.

Assessing scientific evidence is becoming an increasingly common task for international adjudicators. ${ }^{2}$ Evidentiary issues have gradually attracted the attention of international law scholars, who have started investigating the rules and practice of evidence before different international courts and tribunals. ${ }^{3}$ Following this strand of scholarship, this article aims to shed light on the challenges that international courts and tribunals face when adjudicating disputes about NCD prevention measures. As already highlighted by some authors, in fact, these measures raise particularly thorny evidentiary challenges. ${ }^{4}$

1 Alberto Alemanno and Amandine Garde, Regulating Lifestyle Risks: The EU, Alcohol, Tobacco and Unhealthy Diets (CUP 2015).

2 For a definition, see Makane Mbengue, 'International Courts and Tribunals as Fact-Finders: The Case of Scientific Fact-Finding in International Adjudication' (2011) 34 Loy LA Intl \& Comp L J 53.

3 ibid; Chester Brown, A Common Law of International Adjudication (OUP 2009); Caroline E Foster, Science and the Precautionary Principle in International Courts and Tribunals: Expert Evidence, Burden of Proof and Finality (CUP 2011); Anna Riddell, 'Evidence, Fact-Finding, and Experts' in Cesare Romano, Yuval Shany and Karen Alter (eds), The Oxford Handbook of International Adjudication (OUP 2014); James Gerard Devaney, Fact-Finding Before the International Court of Justice (CUP 2016); Frédéric Gilles Sourgens, Kabir AN Duggal and Ian A Laird, Evidence in International Investment Arbitration (OUP 2018).

4 Tania Voon, 'Evidentiary Challenges for Public Health Regulation in International Trade and Investment Law' (2015) 18(4) JIEL 795; Alberto Alemanno and Amandine Garde, 'The Emergence of EU Lifestyle Risk Regulation' in Hans W Micklitz and Takis Tridimas (eds), Risk and EU Law (Edward Elgar 2015); Sergio Puig, 'Internationalization of Tobacco Tactics' (2017) 28 Duke J Comp \& Intl L 495; Sarah A Roache and others, 'Big Food and Soda versus Public 
Challenges to NCD prevention measures often do not concern the dimension of risk assessment (as the risks associated with tobacco, alcohol, and unhealthy food consumption are already established), but that of risk management. This evidence is particularly complex to assess, as it tries to answer questions like: is this measure going to be effective? Are there any other more effective measures? Or, are there any other equally effective measures that entail fewer disadvantages? Moreover, in the case of NCD prevention measures, it is particularly difficult to predict the possible effectiveness of the measures as it would require knowing how people would react to them and to what extent they would change their lifestyle risky (and in some cases addictive) behaviour. Philip Morris is the first international investment dispute where questions on the effectiveness of NCD prevention measures have been answered. Some of the elements of the Tribunal's reasoning on evidence have already been described and criticised. ${ }^{5}$ This article builds on this scholarship, highlighting the specificities of the case, focusing on the relevance of the World Health Organization (WHO) Framework Convention on Tobacco Control (FCTC) ${ }^{6}$ in the assessment of the evidence.

Having been conceived as an 'international regulatory strategy' for tobacco control, ${ }^{7}$ the FCTC sets forth the elements of a comprehensive strategy for tobacco control that its Parties ought to adopt (e.g. health warnings and labelling of tobacco packets, ban on advertising of tobacco products). All these measures are drawn from the experience of states that had successfully reduced smoking prevalence. ${ }^{8}$ For this reason, the FCTC is widely considered an "'evidence-based' treaty". ${ }^{9}$ Similarly, the guidelines for implementation of

Health: Industry Litigation Against Local Government Regulations to Promote Healthy Diets' (2017) 45 Fordham Urb L J 1051.

5 Caroline E Foster, 'Respecting Regulatory Measures: Arbitral Method and Reasoning in the Philip Morris v Uruguay Tobacco Plain Packaging Case' (2017) 26 Review of European, Comparative \& International Environmental Law 287; José E Alvarez, 'The Search for Objectivity: The Use of Experts in Philip Morris v Uruguay' (2018) 9 JIDS 411.

6 WHO Framework Convention on Tobacco Control (opened for signature 16 June 2003, entered into force 27 February 2005) 2302 UNTS 166 (FCTC).

7 Allyn L Taylor, 'An International Regulatory Strategy for Global Tobacco Control' (1996) 21 Yale J Intl L 257 .

8 Paul Cairney, Hadii Mamudu and Donley Studlar, Global Tobacco Control - Power, Policy, Governance and Transfer (Palgrave Macmillan UK 2012) 209.

9 Allyn L Taylor and Douglas W Bettcher, 'WHO Framework Convention on Tobacco Control: A Global Good for Public Health' (2000) 78 Bulletin of the World Health Organization 920; Kenji Shibuya and others, 'WHO Framework Convention on Tobacco Control: Development of an Evidence Based Global Public Health Treaty' (2003) 327 British Medical Journal 154; Matthew L Myers, 'The FCTC's Evidence-Based Policies Remain a Key to Ending the Tobacco 
the FCTC are 'based on the best available evidence, ${ }^{10}$ and are often described as 'evidence-based' by the scholarship. ${ }^{11}$

While the exact meaning and scope of the 'evidence-based' treaty (or 'evidence-based' guidelines) has not been clarified, the relevance of the FCTC and its guidelines in the evidentiary assessment has been invoked before a few other international courts and tribunals; ${ }^{12}$ most notably in some panel reports issued in the context of the World Trade Organization (WTO) dispute settlement system, ${ }^{13}$ and in some judgements of the Court of Justice of the European Union (CJEU). ${ }^{14}$ Like the adjudicators in the CJEU and WTO cases, the Tribunal in Philip Morris seems to have accepted that the FCTC and its

Epidemic' (2013) 22 Tobacco Control i45. This definition also shared by the Conference of the Parties (COP) to the FCTC: 'Policy Options and Recommendations on Economically Sustainable Alternatives to Tobacco Growing (in Relation to Articles 17 and 18)' (2014) FCTC/COP6(11), para 1.

$10 \quad$ FCTC COP, 'Guidelines for Implementation of Article 13: Tobacco Advertising, Promotion and Sponsorship' (2008) FCTC/COP $3(12)$, para $1<$ www.who.int/fctc/guidelines/adopted/ article_13/en/> accessed 30 January 2020.

11 Melanie Wakefield and Jonathan Liberman, 'Back to the Future: Tobacco Industry Interference, Evidence and the Framework Convention on Tobacco Control' (2008) 17 Tobacco Control 145; Raphael Lencucha, Ronald Labonté and Michael J Rouse, 'Beyond Idealism and Realism: Canadian NGO/Government Relations During the Negotiation of the FCTC' (2010) 31 Journal of Public Health Policy 74; Gian Luca Burci, 'Health: Practitioner Comment' in Simon Chesterman, David Malone and Santiago Villalpando (eds), The Oxford Handbook of United Nations Treaties (OUP 2019) 36o.

12 Monique E Muggli and others, "Tracking the Relevance of the WHO Framework Convention on Tobacco Control in Legislation and Litigation Through the Online Resource, Tobacco Control Laws' (2014) 23 Tobacco Control 457; Margherita Melillo, 'The Legal and Evidential Value of the Guidelines for Implementation of the Framework Convention on Tobacco Control: Recent Developments and Critical Views' (2017) 8 European Journal of Risk Regulation 186; Suzanne Y Zhou, Jonathan D Liberman and Evita Ricafort, "The Impact of the WHO Framework Convention on Tobacco Control in Defending Legal Challenges to Tobacco Control Measures' (2018) 28(s) Tobacco Control 113; Lukasz Gruszczynski and Margherita Melillo, "The FCTC and Its Role in WTO Law: Some Remarks on the WTO Plain Packaging Report' (2018) 9 European Journal of Risk Regulation 564.

13 WTO, Dominican Republic - Measures Affecting the Importation and Internal Sale of Cigarettes, Report of the Panel (19 May 2005)WT/DS302/R;WTO, United States-Measures Affecting the Production and Sale of Clove Cigarettes, Report of the Panel (24 April 2012) WT/DS406/R; WTO, Australia - Certain Measures Concerning Trademarks, Geographical Indications and Other Plain Packaging Requirements Applicable to Tobacco Products and Packaging, Reports of the Panels (28 June 2018) WT/DS435/R, WT/DS441/R, WT/ $\mathrm{DS}_{45} 8 / \mathrm{R}$, and WT/DS467/R.

14 CJEU, Case C-358/14, Republic of Poland $v$ European Parliament and Council of the European Union (4 May 2014) ECLI:EU:C:2016:323; CJEU, Case C-547/14, Philip Morris 
guidelines can be relevant for the evidentiary assessment of a tobacco control measure.

The FCTC is not the only international instrument on NCD prevention to be described as evidence-based. More generally, all the other policy options recommended by the WHO Global Action Plan for the Prevention and Control of Noncommunicable Diseases (WHO Global Action Plan for NCDs) are described as being evidence-based. ${ }^{15}$ Could these international instruments be relevant in the evidentiary assessment of an NCD prevention measure challenged before an international court or tribunal?

Finally, the analysis of the evidentiary issues in Philip Morris is also particularly relevant for understanding the practice of presenting and assessing evidence in international investment arbitration. While typically the bulk of the documents submitted in the context of an investment dispute are kept confidential, all the documents of Philip Morris have been published on the database of the Campaign for Tobacco-free Kids. ${ }^{16}$ This includes all the parties' submissions as well as all the witness statements, expert opinions, and exhibits attached to them. This very exceptional circumstance allows us to gain a comprehensive understanding of the evidence submitted and considered in the dispute.

Against this background, this article analyses the assessment of the evidence in the Philip Morris case, with a view to drawing some lessons for possible future disputes concerning NCD prevention measures more broadly. To this end, Section 2 is devoted to understanding the complexity of the evidentiary questions raised in Philip Morris. Section 3 describes the potential legal and evidentiary relevance of the FCTC and its guidelines in the dispute. Section 4 analyses the Tribunal's assessment of evidence, and the role of the FCTC. Finally, Section 5 draws some lessons on the use of an international evidence-based instrument such as the FCTC in an investment dispute, and on the drafting of these instruments more generally.

Brands SARL and Others (4 May 2014) ECLI:EU:C:2016:325; CJEU, Case C-477/14, Pillbox $38(U K)$ Ltd $v$ The Secretary of State for Health (4 May 2014) ECLI:EU:C:2016:324.

15 WHO, 'Global Action Plan for the Prevention and Control of Noncommunicable Diseases 2013-2020' (2013) Appendix 3.

16 Campaign for Tobacco-Free Kids, 'Tobacco Control Laws' <www.tobaccocontrollaws.org/ litigation/spotlight_uruguay/documents $>$ (accessed 30 January 2020). 


\section{$2 \quad$ The Evidentiary Challenges Raised in Philip Morris}

Philip Morris' lawsuit against Uruguay has been widely regarded as the extension of the well-documented tobacco industry tactics to delay and hamper tobacco control regulation. ${ }^{17}$ The choice to target Uruguay was likely influenced by the type of measures that it had adopted. Significantly, the lawsuit focused only on two of the most advanced tobacco control measures adopted by Uruguay: the 'single presentation requirement' (SPR), prohibiting the sale of different packaging of variants of cigarettes sold by a single brand, and an increase in the size of health warnings from $50 \%$ to $80 \%$ of each pack $(80 / 80$ Regulation). At that time, these measures were unprecedented: the SPR was an innovative measure designed by Uruguay, and no other State had yet adopted a measure requiring health warnings to cover $80 \%$ of packs. ${ }^{18}$

Against this backdrop, this Section analyses the evidentiary challenges posed in the dispute, with a view to understanding the specificities and difficulties they pose. Sub-Section 2.1 presents the Claimants' arguments. Sub-Section 2.2 presents an analysis that shows how the Claimants focused their arguments on the innovativeness of the measures. Finally, Sub-Section 2.3 explains why these claims presented complex challenges for both the Respondent and the Tribunal.

\subsection{The Claims About the Effectiveness of the Uruguayan Tobacco Control Measures}

At the core of the dispute, the Claimants' contention was that, by adopting the two abovementioned regulations, Uruguay had violated their rights as investors. Two main claims were brought forward: first, that Uruguay had expropriated the Claimants' intellectual property rights associated with the cigarette brands (in violation of Article 5 of the Switzerland-Uruguay Bilateral Investment Treaty, BIT);19 second, that Uruguay had breached its obligation of fair and equitable treatment (the so-called 'FET clause', Article 3(2) of the BIT $).{ }^{20}$ In addition to the questions related to the nature and the value of the intellectual property rights of the Claimants, these two claims raised critical questions related to the evidence supporting the SPR and the $80 / 80$ Regulation.

\footnotetext{
17 Puig (n 4).

18 Tobacco Labels, 'Uruguay | Tobacco Labelling Regulations' < www.tobaccolabels.ca/coun tries/uruguay/> (accessed 30 January 2020).

19 Philip Morris v Uruguay, ICSID Case no. ARB/10/7, Award (8 July 2016) para 18o.

20 ibid para 309.
} 
Like the regulation of any hazards, regulation of tobacco products can be divided into two phases: risk assessment (i.e. the existence and likelihood of a risk) and risk management (i.e. how to address the risk). It is now beyond controversy that tobacco smoking and exposure to tobacco smoke are harmful and linked to several diseases (i.e. the risk assessment phase). However, this has not exhausted the scientific controversy surrounding tobacco control measures. Since at least the 199os, the tobacco industry has been challenging the scientific rationale behind tobacco control measures (i.e. the risk management phase). ${ }^{21}$ By the same token, the evidentiary challenges raised in Philip Morris concerned the risk management aspects of the SPR and the $80 / 80$ Regulation. In other words, the Claimants did not challenge whether tobacco smoking should be discouraged or not, but rather whether the SPR and the 80/80 Regulation were appropriate to this end.

No provision in the Uruguay-Switzerland BIT expressly requires that the measures adopted should be appropriate to the objectives they want to achieve. However, questions as to the appropriateness of the challenged measures can arise when investment tribunals adopt a proportionality test for assessing BIT clauses (often the FET clause, but also expropriation and other clauses). ${ }^{22}$ Although proportionality tests are not required by most BITs, investment tribunals seem to be adopting them more and more, both in explicit and in implicit terms. ${ }^{23}$ Academics have started questioning whether the use of a proportionality test is generally justified or even desirable in international investment law. ${ }^{24}$ As already noted by other authors, in fact, the evidentiary difficulties posed by NCD measures make very 'problematic' the application of any proportionality tests. ${ }^{25}$ Nonetheless, the Tribunal in Philip Morris decided to follow this jurisprudential trend, and applied a proportionality test to assess the claim about the alleged violation of the FET clause under Article 3(2)

21 Hadii M Mamudu, Ross Hammond and Stanton Glantz, 'Tobacco Industry Attempts to Counter the World Bank Report Curbing the Epidemic and Obstruct the WHO Framework Convention on Tobacco Control' (2008) 67 Social Science \& Medicine 1690.

22 Benedict Kingsbury and Stephan W Schill, 'Public Law Concepts to Balance Investors' Rights with State Regulatory Actions in the Public Interest - The Concept of Proportionality' (2010) 75 International Investment Law and Comparative Public Law 97.

23 Valentina Vadi, Proportionality, Reasonableness and Standards of Review in International Investment Law and Arbitration (Edward Elgar 2018) 105.

24 ibid ch 3; N Jansen Calamita, "The Principle of Proportionality and the Problem of Indeterminacy in International Investment Treaty' in Andrea K Bjorklund (ed), Yearbook on International Investment Law \& Policy 2013-2014 (OUP 2015) ch 5; Federico Ortino, 'Investment Treaties, Sustainable Development and Reasonableness Review: A Case Against Strict Proportionality Balancing' (2017) 3o LJIL 71.

Alemanno and Garde (n 4) 155 . 
of the BIT, ${ }^{26}$ which in turn required an assessment of the evidence supporting the Uruguayan measures: were the measures adopted by Uruguay effective, or were they damaging the Claimants' investment without having significant effects?

With respect to the alleged expropriation under Article 5 of the BIT, the question over the appropriateness of the measures was indirectly raised in Uruguay's defence. Uruguay maintained that the SPR and 80/80 Regulation did not amount to an indirect expropriation, but that, even if they did, they would be justified under the so-called doctrine of 'police powers'.27 According to the case-law followed by the Tribunal, an assessment of whether a State had legitimately exercised its police powers involves stating whether the measures adopted were arbitrary, ${ }^{28}$ which, in turn, required an assessment very similar to that under the FET clause. Hence, again, the essential question that the adjudicators were facing concerned the effectiveness of the measures adopted by Uruguay.

\subsection{Layers of Evidence: Which Evidence Is Really Challenged?}

As shown above, the Claimants challenged only the appropriateness of the SPR and of the $80 / 80$ Regulation (the risk management dimension). Moreover, it is essential to highlight that the Claimants did not challenge the general appropriateness of the measures (e.g. the adoption of health warnings), but only the specific 'innovativeness' of the SPR and of the 80/80 Regulation.

To explain this point, I decompose each challenged measure into what I call 'layers of evidence'. It is possible to think of the evidence supporting tobacco control measures as the result of the accumulation of scientific studies on tobacco control: a multi-layered stack of evidence that, step-by-step, supports the scientific rationale of the newest and most advanced tobacco control measures.

Before proceeding, it is imperative to clarify what I mean by 'evidence'. In its more general definition, evidence is ' $[t]$ he available body of facts or information indicating whether a belief or proposition is true or valid. ${ }^{29}$ This definition is very broad and can include observations that indicate that a fact is true (e.g. a measure restricting tobacco advertising has been adopted), but do not necessarily confirm a scientific theory (e.g. tobacco control measures reduce

\footnotetext{
26 Philip Morris v Uruguay, Award (n 19) para 305.

27 ibid paras 216-17.

28 ibid para 306.

29 'Evidence - Definition of Evidence in English by Lexico Dictionaries' (Lexico Dictionaries) $<$ www.lexico.com/en/definition/evidence > accessed 25 July 2019.
} 
smoking prevalence). This paper adopts a more restrictive definition of evidence, which includes only evidence related to scientific facts. In this context, importantly, 'scientific' refers to both the natural and the social sciences. ${ }^{30}$ The evidence on the risk management phase of tobacco control, in fact, is multidisciplinary in nature, as it is based on studies in epidemiology, public health, economics, and psychology. ${ }^{31}$

Starting with the SPR, the general rationale behind this measure is that regulating tobacco packaging is a suitable measure for reducing smoking prevalence (first layer of evidence). Although tobacco packages have been regulated since the 196os, subsequent studies have shown that adding labels and health warnings to tobacco packages are cost-effective measures. ${ }^{32}$ An additional problem arises when some packets of cigarettes are deceptively labelled as 'light' or 'mild', and this erroneously leads consumers to think that smoking certain cigarettes can be less harmful (second layer of evidence). However, banning the use of these descriptors is not sufficient. Indeed, Uruguay contended that the ban had proven ineffective because the tobacco companies kept marketing the same cigarettes under another name (such as 'gold') while keeping their distinctive packaging and colours to make them identifiable as less harmful (third layer of evidence). The SPR was accordingly designed to overcome this problem by prohibiting the sale of different variants by a single brand, and thus making different cigarettes packs indistinguishable.

The $80 / 8$ o Regulation is similarly the result of the accumulation of evidence on how to design the most effective measure for tobacco control. Following the same methodology, it is possible to decompose this measure into three layers: evidence that regulating tobacco packaging is a suitable measure for reducing smoking prevalence (first layer of evidence); evidence that adding health warnings is a suitable measure to regulate tobacco packaging (second layer of evidence); evidence that bigger health warnings are more effective (third layer of evidence).

In Philip Morris, the Claimants did not challenge the first and second layers of evidence of the SPR and of the 8o/80 Regulation, but only and specifically

$30 \quad$ I adopt the definition of 'scientific' and 'sciences' laid down in UNESCO, 'Recommendation on Science and Scientific Researchers of Resolution 15' (adopted by the General Conference, thirty-ninth session, 13 November 2017) 39 C/Res.15.

31 Executive Board of the WHO Resolution, 'Tobacco Smoking and Its Effects on Health' (1974) EB53.R31.

32 World Bank, 'Curbing the Epidemic - Governments and the Economics of Tobacco Control' (1999) 45-48 <http://documents.worldbank.org/curated/en/914041468176678 949/Curbing-the-epidemic-governments-and-the-economics-of-tobacco-control> accessed 20 April 2017. 
the third layer. ${ }^{33}$ In other words, the questions asked were: is the SPR really needed? Is it not enough to ban the use of 'light' descriptors? Moreover, is it really beneficial to have health warnings covering $80 \%$ of the surface of cigarette packs, as opposed to $50 \%$ ?

\subsection{The Difficulty of Assessing the Evidence}

The assessment of the third layers of evidence described above poses several difficulties. For Uruguay (as for any respondent in a similar case) it is challenging to find conclusive evidence on the effectiveness of a tobacco control or of an NCD prevention regulation measure, for two main reasons.

The first is that many of the measures are expected to have effects mostly in the long term, preventing the onset of smoking in children and young adults. This is part of what the tobacco control community dubs the process of 'denormalisation' of tobacco smoking. ${ }^{34}$ The same type of long-term measures is applied to prevent other 'lifestyle risks'. ${ }^{35}$ However, as in the case of Uruguay, legal challenges are typically brought shortly after the measures are implemented, when the long-term effects cannot yet be demonstrated.

The second reason is that there is no one obvious solution to a societal issue as difficult and as diffused as tobacco smoking. While certain health risks can be addressed by banning a hazardous substance (like asbestos), banning tobacco products raises many more ethical questions (what about individual freedom?), and practical issues (most notably, risk of increase in illicit trade). Following a long-held principle of public health studies in the field, the FCTC mandates a 'comprehensive' multisectoral approach in dealing with tobacco control, which includes measures such as taxes, health warnings, bans on advertising, and smoke-free areas. ${ }^{36}$ Similarly, the WHO Global Action Plan for NCDs proposes a comprehensive approach in dealing with the harmful use of alcohol, unhealthy diet, and physical inactivity. ${ }^{37}$ As these measures are typically implemented at the same time, it becomes very hard to appraise the effects of each individual measure.

In the Uruguay dispute, these difficulties translated into a hefty amount of evidence submitted by the parties. Twenty-six party-appointed experts and witnesses participated in the hearings. ${ }^{38}$ Additionally, Uruguay submitted

\footnotetext{
33 Philip Morris v Uruguay, Award (n 19) paras 31-38, 52.

34 WHO, 'Tobacco and Youth' <www.who.int/tobacco/control/populations/youth/en/ indexı.html $>$ accessed 18 December 2018.

35 Alemanno and Garde (n 1).

$36 \quad$ FCTC (n 6) art 7.

37 WHO (n 15).

$38 \quad$ Philip Morris v Uruguay, Award (n 19) para 56.
} 
a considerable number of reports and journal articles on public health. Considering the letters, emails, tobacco internal reports, and all the other documents submitted before the Tribunal, the parties jointly submitted 963 exhibits. ${ }^{39}$ How can a Tribunal assess a dispute where there is such an enormous amount of opposing evidence? One answer was found in the FCTC.

\section{3 \\ The Relevance of the FCTC in the Dispute}

That the FCTC was a key element of the dispute was clear from the outset. The FCTC was immediately mentioned by the Claimants in their Request for Arbitration. ${ }^{40}$ However, as the next Sub-Section 3.1 explains, it soon became clear that it would be very difficult to consider the FCTC and the guidelines the applicable law in the dispute. This, nevertheless, did not prevent the FCTC from being relevant for the evidentiary assessment, as described in subsection 3.2.

\subsection{The FCTC Obligations and the Guidelines' Recommendations}

The FCTC does not mandate measures such as the Uruguayan SPR and 8o/8o Regulation. Nevertheless, as is also acknowledged in the text of the Uruguayan legislation, it is beyond doubt that both measures were adopted to implement FCTC obligations. ${ }^{41}$

Article 11 of the FCTC mandates that Parties adopt measures to ensure that packets and packaging of tobacco products are not false or misleading. ${ }^{42}$ Moreover, the Guidelines to Article 11 recommend that Parties regulate not only language signs such as 'light', but also any 'trademark or figurative or other signs' that would create the same impression of safer cigarettes. ${ }^{43}$ These two provisions support the rationale of the SPR: to prevent smokers from being misled into thinking that some cigarette packets contain 'lighter' cigarettes. Similarly, the rationale of the $80 / 8$ o Regulation (big health warnings)

39 ibid 'List of Exhibits' <www.tobaccocontrollaws.org/files/uruguay/MASTER\%2oExhibit \%2oIndex.pdf> accessed 16 December 2017.

40 Philip Morris v Uruguay, ICSID Case no ARB/10/7, Request for Arbitration (19 February 2010).

41 Smoking Control Regulations (Uruguay) Law No 18,256 (6 March 2008) art 2; an unofficial translation is provided at <www.tobaccocontrollaws.org/files/live/Uruguay/ Uruguay\%2o-\%2oLaw\%2oNo.\%2018.256.pdf> accessed 16 December 2017.

$42 \quad$ FCTC (n 6) art $11(1)(a)$.

43 FCTC COP, 'Guidelines for Implementation of Article 11 of the WHO Framework Convention on Tobacco Control, Packaging and Labelling of Tobacco Products' (November 2008) FCTC/COP $3(10)$ para 43. 
is supported by the FCTC and the guidelines. The FCTC provides that the Parties should ensure that packets and packaging of tobacco products 'carry health warnings ... [ covering] $50 \%$ or more of the principal display areas. ${ }^{4} 4$ Furthermore, the Guidelines to Article 11 recommend that the Parties consider adopting health warnings that cover 'more than $50 \%$ ' and aim to cover 'as much of the principal display areas as possible. 45

In addition, it should be highlighted that the general obligation under Article 11 of the FCTC is that parties adopt effective measures. ${ }^{46}$ In this respect, the SPR and the 80/80 Regulation can be considered an implementation of the general obligation under Article 11. Despite the fact that the SPR and the 80/80 Regulation fall within the scope of the FCTC obligations and recommendations, however, the FCTC could not inform the interpretation of the BIT provisions challenged by the Claimants. ${ }^{47}$ Switzerland, the other party to the BIT, never ratified the FCTC. ${ }^{48}$ Even if this problem was overcome, it should be borne in mind that the legal status of the FCTC guidelines is still controversial. ${ }^{49}$ However, it is exactly in these guidelines that many of the relevant provisions supporting the challenged measures are contained.

The difficulties of recognising the FCTC and the guidelines as applicable law in the dispute, however, did not prevent the FCTC from being relevant for a different reason: the authoritativeness of their provisions, which, in addition to being adopted by 181 Parties, are evidence-based.

\footnotetext{
$44 \quad$ FCTC (n 6) art 11(1)(b)(iv).

45 Guidelines for Implementation of Article 11 (n 43) para 12.

$46 \quad$ FCTC (n 6) art $11(1)$.

47 Other possibilities have been explored. See Valentina Vadi, 'Global Health Governance at a Crossroads: Trademark Protection v Tobacco Control in International Investment Law' (2012) 48 Stan J Intl L 93.

48 WHO Framework Convention on Tobacco Control (adopted at the 56th World Health Assembly, 19-28 May 2003) <https://treaties.un.org/pages/ViewDetails.aspx?src=TREATY \&mtdsg_no=IX-4\&chapter=9\&clang=_en $>$ accessed 18 December 2018.

49 Sam Foster Halabi, 'The World Health Organization's Framework Convention on Tobacco Control: An Analysis of Guidelines Adopted by the Conference of the Parties' (2010) 39 Ga J Intl \& Comp L 121; Tsai-yu Lin, 'The Status of FCTC in the Interpretation of Compensable Indirect Expropriation and the Right to Adopt Stricter Tobacco Control Measures Under BITs' (2014) 9 Asian J WTO \& Intl Health L \& Poly 123; Jonathan Liberman, 'The Power of the WHO FCTC: Understanding Its Legal Status and Weight' in Andrew Mitchell and Tania Voon (eds), The Global Tobacco Epidemic and the Law (Edward Elgar 2014) 48.
} 

Submissions

The FCTC was mentioned from the beginning of the dispute by the Claimants, though mostly for underplaying its importance. In the Request for Arbitration, a footnote pointed out the fact that, although Uruguay's legislation claimed to implement them, neither the text of the FCTC nor that of the guidelines recommended a measure such as the SPR. ${ }^{50}$ References to the FCTC completely disappeared in the Claimants' first submission on the merits..$^{51}$ Given the tobacco industry's track record in fighting the FCTC, ${ }^{52}$ this choice was probably the result of a litigation strategy by the Claimants.

Uruguay, on the other hand, placed particular emphasis on the fact that the two challenged measures had been introduced to comply with its international obligations. ${ }^{53}$ Moreover, it briefly referred to the relevance of the FCTC and its guidelines for the evidentiary assessment. ${ }^{54}$ Interestingly, however, Uruguay's submissions were partially re-shaped after the intervention of two amici curiae. In February and March 2015, the Tribunal accepted two briefs: one jointly submitted by the WHO and by the FCTC Secretariat (WHO/FCTC), and one by the regional office of the WHO responsible for the Americas, the Pan-American Health Organization (PAHO). Although they had a different narrative and context, both submissions pointed at the bodies of evidence supporting the Uruguayan measures. The Tribunal praised both briefs for the 'particular knowledge and expertise' that the WHO/FCTC and PAHO briefs would bring to the case. ${ }^{55}$

Uruguay made the best possible use of the two submissions, quoting them in virtually all relevant sections. The amici curiae briefs became the first piece of evidence cited by Uruguay in defending the SPR measure. ${ }^{56}$ At this point, Uruguay trusted that the Tribunal would rely on expert evidence originating from 'international bodies', as it remarked that other international dispute settlement bodies had done so before, ${ }^{57}$ citing, inter alia, the use made of the

50 Philip Morris v Uruguay, Request for Arbitration (n 40).

$5^{1}$ Philip Morris $v$ Uruguay, ICSID Case no. ARB/10/7, Claimants' Memorial on the Merits (3 March 2014).

52 Mamudu, Hammond and Glantz (n 21).

53 Philip Morris v Uruguay, ICSID Case No ARB/10/7, Uruguay's Counter-Memorial on the Merits (13 October 2014) ch II(2).

54 ibid paras 5.25-5.28.

55 Philip Morrisv Uruguay, ICSID Case No ARB /10/7, Procedural Order n 3 (17 February 2015); Philip Morris v Uruguay, ICSID Case No ARB/10/7, Procedural Order n 4 (24 March 2015).

56 Philip Morris $v$ Uruguay, ICSID Case No ARB $/ 10 / 7$, Uruguay's Rejoinder on the Merits (20 September 2015) 35-41, and paras 3.49-3.51, 3.57-3.59.

57 ibid para 1.6. 
FCTC guidelines by the WTO panel in the Clove Cigarette dispute. ${ }^{58}$ In this respect, it is interesting to note how the intervention of the amici curiae in this dispute shaped the Respondent's defence before even becoming relevant to the Award.

At the same time, the Claimants failed to challenge the broader relevance of the FCTC. They only observed that the FCTC and its guidelines could not be considered part of the applicable law to the dispute, ${ }^{59}$ thus neglecting their broader importance for the evidentiary assessment. By the same token, the Claimants did not try to make specific claims on why the WHO/FCTC and PAHO amici curiae briefs should not be taken into account for the expertise they provided. The absence of meaningful counter-arguments to the broader relevance of the FCTC and of the amici curiae briefs in the Claimants' submission was duly noted by Uruguay. ${ }^{60}$ Lacking counter-arguments, the Tribunal confirmed the relevance of the FCTC, of its guidelines, as well as of the WHO/ FCTC and PAHO submissions for the evidentiary assessment, as described below.

\section{The Assessment of Evidence in Philip Morris, and the Role} of the FCTC

In the Award, the Tribunal noted that the FCTC and the guidelines were generally part of the relevant international regulatory framework. ${ }^{61}$ Furthermore, the Tribunal greatly relied on these instruments, as well as on the amici curiae submissions, for its evidentiary assessment.

As Section 2 has outlined, the amount of evidence submitted in Philip Morris potentially made its assessment very difficult. The following sub-sections summarise the arguments presented by the parties on the evidence supporting the two measures, as well as the Tribunal's assessment and the role of the FCTC. For reasons of concision, and because this was also the most interesting part of the Tribunal's analysis, the focus is only on the assessment of evidence relevant to the claim of violation of the FET clause. ${ }^{62}$ Three main issues were

\footnotetext{
58 ibid fn 4.

59 Philip Morris v Uruguay, ICSID Case No ARB/10/7, Claimants' Reply on the Merits (17 April 2015) paras 100-03.

6o Philip Morris v Uruguay, Uruguay's Rejoinder on the Merits (n 56 ) paras 1.2-1.6.

61 Philip Morris v Uruguay, Award (n 19) paras 19-23.

62 With respect to the claim of expropriation seen above the Tribunal held that the adoption of the two tobacco control regulations by Uruguay did not constitute an expropriation measure. Although the Tribunal went on to describe why, even if the measures were
} 
challenged and analysed: whether the measures had been adopted following a review of scientific evidence (Sub-Section 4.1), whether the measures could achieve their goals (Sub-Section 4.2), and whether the measures did achieve their goals (Sub-Section 4.3).

\subsection{Whether the Measures Had Been Adopted Following a Review of Scientific Evidence}

With respect to the first issue, the Claimants argued that Uruguay had adopted the two measures without reviewing the relevant scientific evidence on their effects. ${ }^{63}$ Some witnesses confirmed the claim. ${ }^{64}$ Uruguay's witnesses, including the then Minister of Health, testified to the contrary. ${ }^{65}$ Moreover, during document discovery, the Claimants asked Uruguay to provide the documents in which evidence on the adoption of the two measures would have been considered and assessed. ${ }^{66}$ However, Uruguay failed to provide any significant document. ${ }^{67}$

The Tribunal only noted that at the time the measures were adopted evidence 'was available', 68 and cited some of the scientific studies submitted by Uruguay during the proceedings. ${ }^{69}$ Saying that evidence was available does not imply that Uruguay had actually taken these studies into account when adopting the regulations. Very importantly, however, the Tribunal took note of Uruguay's long-standing and committed participation to the works of the FCTC, and held that this process had provided Uruguay with the necessary tools to adopt sound scientific tobacco control policies. The Tribunal recalled that the guidelines to the FCTC are evidence-based. Accordingly, participation in their development meant that Uruguay had access to the evidence on which they are based. ${ }^{70}$ By participating in the process, Uruguay had acquired the necessary knowledge and expertise to adopt the SPR and 8o/8o Regulation. ${ }^{71}$ Accordingly, the simple participation in the works of the FCTC was considered

deemed an action of expropriation, they would have been justified by the so-called police power doctrine, the evidentiary analysis on this point was very limited. See Philip Morris v Uruguay, Award (n 19) paras 287-306.

63 Philip Morris v Uruguay, Claimants' Reply on the Merits (n 59) paras 44-46.

64 ibid.

65 Philip Morris v Uruguay, Uruguay's Counter-Memorial on the Merits (n 53) paras 4.98-4.106.

66 Philip Morris v Uruguay, Award (n 19) paras 47-52, 74.

67 ibid.

68 ibid para 392.

69 ibid.

70 ibid paras $393-94$.

71 ibid paras $393-96$. 
sufficient to fulfil the requirement of adopting reasonable measures without the need to perform any additional studies. ${ }^{72}$

Moreover, the Tribunal conceded that no detailed research had been done before the adoption of the SPR, and that, in any case, it would have been difficult to do so because of its innovativeness. ${ }^{73}$ In other words, and contrary to the Claimants' assertions, the Tribunal held that it would be unreasonable to ask Uruguay to carry out a review of scientific evidence that covers the third layer of evidence.

\subsection{Whether the Measures Could Achieve Their Goals}

Furthermore, the Claimants argued that the two challenged measures were arbitrary because the measures that were in place before them (the ban on light cigarettes in lieu of the SPR, and the health warnings at $50 \%$ in lieu of the $80 / 80$ Regulation) were already attaining their objectives. Therefore, in addition to claiming that Uruguay had not reviewed the existing evidence before adopting the measures, the Claimants argued that Uruguay failed to prove their scientific basis after having adopted them, and specifically that they did not submit evidence related to the third layer.

Concerning the SPR, the Claimants argued that the association between some colours like gold and lighter cigarettes was undemonstrated, and it was contradicted by some examples of golden-packaged but not light cigarettes. ${ }^{74}$ With respect to the $80 / 80$ Regulation, the Claimants argued that there was no evidence proving that health warnings covering $80 \%$ of the package would be more effective in communicating the risks associated with smoking than health warnings covering $50 \% .{ }^{75}$ To this end, they submitted reviews of existing evidence carried out by their appointed experts, in which they tried to point out the main methodological flaws of the scientific studies that were supporting Uruguay's position. ${ }^{76}$

In response to this, Uruguay submitted an enormous amount of evidence. However, it started with issues that had not even been challenged by the Claimants: why smoking is hazardous (which is part of the risk assessment phase, and not of the risk management), ${ }^{77}$ or why the so-called light cigarettes are no less harmful than ordinary ones (the second layer of evidence of

\footnotetext{
72 ibid para 396.

73 ibid para 407 .

74 Philip Morris v Uruguay, Claimants' Memorial on the Merits' (n 51) paras 31-38.

75 ibid para 5 .

76 ibid paras 142-57; Philip Morris v Uruguay, Claimants' Reply on the Merits (n 59) paras $57-61,77$.

77 Philip Morris v Uruguay, Uruguay's Counter-Memorial on the Merits (n 53) 44-58.
} 
the SPR). ${ }^{78}$ The Tribunal did not delve into this long and complex history; it noted that the Claimants had not challenged it, and it was the 'scientific consensus' that smoking any cigarettes should be just avoided. ${ }^{79}$

After dwelling on uncontroversial evidence, Uruguay submitted evidence proving the second and third layers of evidence of the SPR, i.e. different variants of the same brand perpetuate the impression that some cigarettes are safer than others. It submitted substantial evidence showing that tobacco companies had replaced light with gold cigarettes, that they sought to communicate the shift to the public, ${ }^{80}$ and that the strategy had an effect on consumers. ${ }^{81}$ The FCTC was part of this defence only as proof of the 'international consensus' on prohibiting deceptive packaging (the first layer of evidence). ${ }^{82}$ Nevertheless, as noted above, after the intervention of the amici curiae, Uruguay re-shaped its arguments. In the second memorial, it mostly relied on the WHO/FCTC submission and on the FCTC itself to justify the rationale of the SPR (the second and third layers of evidence). ${ }^{83}$

Uruguay took a relatively more straightforward approach to justify the scientific grounds of the $80 / 8$ o Regulation. From the very beginning of the dispute, it did not deem it necessary to prove the first and second uncontroversial layers of evidence of the $80 / 80$ Regulation. On the contrary, it directly referred to the studies proving the third layer of evidence supporting the measure (i.e. bigger health warnings are more effective), ${ }^{84}$ and to the fact that the FCTC guidelines clearly recognise and refer to this evidence. ${ }^{85}$

Faced with this vast amount of opposing evidence from the two sides of the dispute, the Tribunal avoided making a thorough and complex assessment. First, it noted that the two WHO/FCTC and PAHO submissions recognised the 'utility' (i.e. effectiveness) of the two measures. ${ }^{86}$ Moreover, it made a general remark on the relevance of the FCTC, noting that '[i]n the Tribunal's view, the FCTC is a point of reference on the basis of which to determine the reasonableness of the two measures.' ${ }^{87}$

78 ibid 10o-23.

79 Philip Morris v Uruguay, Award (n 19) para 405.

8o Philip Morris v Uruguay, Uruguay's Counter-Memorial on the Merits (n 53) 131-47.

81 ibid 16o-66.

82 ibid paras 4.60-4.67.

83 Philip Morris v Uruguay, Uruguay's Rejoinder on the Merits (n 59) 35-48.

84 Philip Morris v Uruguay, Award (n 19) para 152, fn 238.

85 Philip Morris v Uruguay, Uruguay's Counter-Memorial on the Merits (n 53) 171-95.

$86 \quad$ Philip Morris v Uruguay, Award (n 19) para 391.

87 ibid para 401. 
In upholding the SPR, the Tribunal recalled that Article 11(1)(a) of the FCTC supported the objective of the SPR. ${ }^{88}$ However, it also recognised that the SPR was not explicitly recommended by the FCTC or by the guidelines. ${ }^{89}$ The Tribunal seemed sympathetic to the arguments of the Claimants that the SPR had not proved very effective. It stated that, being an innovative measure, the SPR might have well fallen short of targeting what was needed to achieve its aim. ${ }^{90}$ However, the Tribunal decided to leave aside the notion of effectiveness strictly-speaking, and it limited its analysis to hold that 'the rationale' for the adoption of the SPR was 'supported by the evidence'. ${ }^{91}$ Only one source of evidence was cited to this purpose: the WHO/FCTC submission. In conclusion, it seems the FCTC was used only to illustrate the legal basis of the measure as well as the 'rationale' for its adoption (the second layer of evidence). The WHO/FCTC submission was instead instrumental in justifying the third layer.

With respect to the $80 / 80$ Regulation, the Tribunal remarked that this measure had been adopted following the adoption of the Guidelines to Article 11, which recommended that health warnings cover 'as much as possible' of the principal display area. ${ }^{92}$ No other piece of evidence was cited to justify the size of the health warnings, but the Tribunal concluded that the decision to choose a specific percentage $(70 \%, 80 \%$ or any other percentage) was 'a matter of public policy, to be left to the appreciation of the regulatory authority' ${ }^{\prime 3} \mathrm{In}$ this respect, the Tribunal deemed the FCTC guidelines enough to justify the third layer of evidence.

\subsection{Whether the Measures Did Achieve Their Goals}

The last question sparked a relatively shorter discussion in this long and dense Award. The Claimants submitted statistics on smoking consumption before and after the regulations, arguing that the reduction in smoking consumption that could be observed after the adoption of the two measures was, in fact, part of a trend that started in 2003. ${ }^{94}$ Moreover, relying on their experts, they argued that the two regulations had spurred smokers to buy illegal or irregular cigarettes. ${ }^{95}$ Uruguay responded with several arguments. First, it maintained

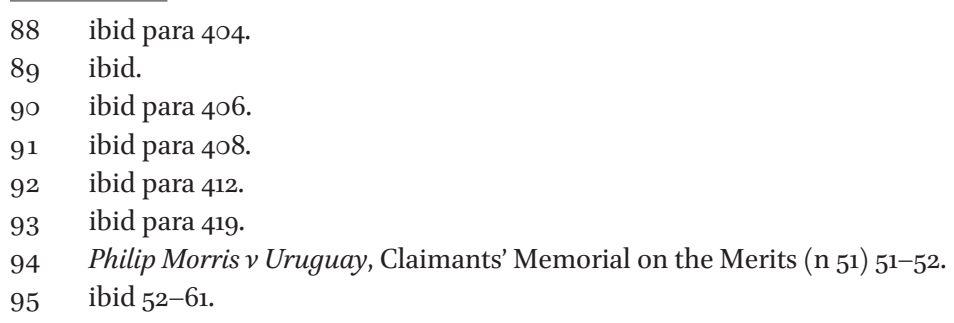


that the reasonableness of the two measures should be assessed a priori and not based on their ex post effects. ${ }^{96}$ Second, it submitted some surveys showing that the two measures had achieved their goal of raising awareness on the risks associated with smoking and of reducing smoking prevalence among young people, ${ }^{97}$ and that, in any case, the Claimants' reading of the statistics was biased and flawed. ${ }^{98}$ Finally, Uruguay argued that the statistics on the market of illicit and irregular cigarettes were unreliable. ${ }^{99}$

In assessing this third issue, the Tribunal only noted that the marketing evidence submitted by the parties was 'discordant'. ${ }^{100}$ Concerning the claim of an increase in illicit and irregular trade, the Tribunal held that the claimants had not met the burden of proof of showing that this was caused by the two regulations. ${ }^{101}$ Furthermore, and very importantly, sharing Uruguay's view on the point, the Tribunal held that deciding on the ex post effects of the measure was not necessary for the purposes of the Award. ${ }^{102}$ By doing so, the Tribunal placed additional emphasis on the relevance of an a priori analysis, and consequently on the role of the FCTC and of its guidelines described in the previous Sub-Section.

\subsection{Conclusions on the Tribunal's Assessment of the Evidentiary Challenges}

The analysis presented above shows that overall (like in other investment disputes where sensitive issues were at stake) the Tribunal adopted a very deferential stance towards Uruguay's sovereign choices. ${ }^{103}$ Although the Tribunal decided that it would apply a proportionality test, in practice the application of the test was loose.

Unlike other international courts and tribunals, ${ }^{104}$ international investment tribunals enjoy a wide margin of discretion in dealing with evidentiary

\footnotetext{
$96 \quad$ Philip Morris v Uruguay, Uruguay's Counter-Memorial on the Merits (n 53) para 6.31.

97 ibid 229-36.

98 Philip Morris v Uruguay, Uruguay's Rejoinder on the Merits (n 56) 104-07.

99 ibid 112-20.

100 Philip Morris v Uruguay, Award (n 19) para 408.

101 ibid para 415 .

102 ibid para 409.

103 Cf Lukasz Gruszczynski and Valentina Vadi, 'Standard of Review and Scientific Evidence in WTO Law and International Investment Arbitration: Converging Parallels?' in Lukasz Gruszczynski and Wouter Werner (eds), Deference in International Courts and Tribunals: Standard of Review and Margin of Appreciation (OUP 2014) 152, 160-164.

104 WTO, Korea: Definitive Safeguard Measure on Imports of Certain Dairy Products, Report of the Appellate Body (14 December 1999) WT/DS98/AB/R, para 137.
} 
matters. ${ }^{105}$ The Tribunal in Philip Morris used this discretion and did not carry out a comprehensive assessment of the evidence presented before it. Rather, it selectively quoted the pieces of evidence it deemed most relevant, without explaining the rationale for its choice. The FCTC and the amici curiae submissions were instrumental in allowing the Tribunal to rely on authoritative sources of evidence without carrying out a comprehensive assessment.

\section{International Evidence-Based Instruments and the Evidentiary Assessment in Investment Disputes: Lessons for NCD Prevention Regulation}

As the contributions in this Special Issue underline, the upsurge of NCD prevention measures may spark other international investment claims. How could national governments best react to such challenges and make sure that they have evidence to support their measures?

As of today, Philip Morris is the only publicly available international investment award issued in the context of a claim against an NCD prevention regulation. However, as remarked in the introduction to this article, tobacco control regulations have been challenged before other international courts and tribunals. A full comparison between these judgements is not possible, for international courts and tribunals have different jurisdiction and procedures, and in particular different rules on evidence ${ }^{106}$ and different standards of review. ${ }^{107}$ However, on a limited number of issues, references to other rulings can help shed light on the limitations and possibilities offered by an international evidence-based instrument such as the FCTC.

The following sub-sections take stock of the lessons learnt in Philip Morris and in other international disputes, with a view to understanding to what extent the use of evidence-based international instruments as evidence can be replicated and/or improved. The analysis focuses on five main issues: challenges and defence strategy (Sub-Section 5.1), developing international evidence-based instruments (Sub-Section 5.2), improving the drafting of evidence-based instruments (Sub-Section 5.3), recognising the relevance of such instruments in litigation (Sub-Section 5.4), and the importance of participating in the international evidence-based processes (Sub-Section 5.5).

\footnotetext{
105 Sourgens, Duggal and Laird (n 3$)$ 71-73.

106 Riddell (n 3 ).

107 Gruszczynski and Werner (n 103).
} 


\subsection{Challenges and Defence Strategy}

Sub-Section 2.1 has used the analogy of layers of evidence to highlight how the Claimants focused their claims on the innovativeness of the Uruguayan measures (i.e. the last layers of evidence). The same strategy has been used in the other international disputes, and most notably in the Plain Packaging case at the WTO. ${ }^{108}$ The reason, in my view, is that it is in these cases that the tobacco industry expects the evidence base to be weaker, and hence to have more chances that the measures are deemed ineffective and unreasonable. We can, accordingly, expect a similar strategy for future cases on NCD prevention measures: always and only targeting the most innovative features of the measures.

The completeness of the Philip Morris dispute's files has allowed us to peek into Uruguay's defence strategy. Section 4, and particularly Sub-Section 4.2, has shown that Uruguay focused a lot of its defence on presenting studies and data on the hazards of tobacco smoking in general and of 'light' cigarettes to justify the SPR. The Tribunal soon dismissed these points, noting that they had not been challenged by the Claimants and represent scientific consensus. Only after the intervention of the amici curiae, Uruguay changed its defence to focus its arguments on references to the amici curiae briefs, and through these, to the FCTC and the guidelines.

Uruguay's strategy was possibly the result of a cautious approach, or of the wish to explain its measures as part of the long and difficult history of tobacco control regulation. In a possible future dispute, however, the defendant would probably be better off trying to devote less time to prove uncontroversial facts, and focusing directly on why the specific measures adopted are supported by evidence. In Philip Morris, the intervention of the amici curiae helped Uruguay focus its defence on the right issues; however, the WHO, the FCTC and the regional WHO offices may not always have the resources or the authorisation to intervene.

\subsection{Developing International Evidence-Based Instruments}

An interesting and related issue is to reflect on the Claimant's choice to target the attack only on the two most innovative measures. This choice implicitly conceded that some of the other tobacco control regulations enacted by Uruguay could be justified. How did they draw the line between which tobacco control measures can be justified, and which cannot? The SPR and the 8o/80

108 WTO, Australia - Certain Measures Concerning Trademarks, Geographical Indications and Other Plain Packaging Requirements Applicable to Tobacco Products and Packaging, Reports of the Panels (28 June 2018) WT/DS435/R, WT/DS441/R, WT/DS458/R, and WT/ $\mathrm{DS}_{4} 67 / \mathrm{R}$. 
Regulation were unprecedented and very advanced. Importantly, they are also not explicitly foreseen by the FCTC and its guidelines, while both a ban on 'light' cigarettes and 50\% health warnings are.

As noted in the introduction, the FCTC and the guidelines are developed following an evidence-based process, which is mostly based on the best experience of State parties. This means that the FCTC and the guidelines recommend measures that have been already adopted by some States. In this respect, the FCTC and the guidelines are probably not the reason why some tobacco control measures become uncontroversial; however, they certainly add clarity to the general understanding of which tobacco control measures are effective. To a certain extent, even the tobacco industry seems to accept that they enshrine this knowledge. This fact highlights the importance of developing evidence-based policy options in future instruments for NCD prevention regulation that will be developed after the WHO Global Action Plan for NCDs.

It is doubted whether an international treaty on NCD prevention regulation or issue like alcohol control could be politically feasible or, perhaps, even desirable. ${ }^{109}$ In the meantime, however, the international community should continue developing the existing evidence-based policy options for NCD prevention regulation, by making them more detailed and specific. Regardless of whether these instruments can be considered applicable law, their strength will lie in their contribution to the evidentiary assessment. In this respect, it is worth noting that the international courts and tribunals that adjudicated tobacco control cases (the Tribunal in Philip Morris, the WTO panels, and the CJEU) relied equally on the FCTC and on its guidelines for the evidentiary assessment, irrespective of their legal status and relevance. ${ }^{110}$

\subsection{Improving the Drafting of Evidence-Based International Instruments, While Spurring Innovation and Taking into Account National Circumstances}

Nevertheless, the evidence-based nature of international instruments such as the FCTC and its guidelines may also potentially become a double-edged sword. We should improve the drafting process in order to prevent potential negative implications.

\footnotetext{
109 G Lien and K DeLand, 'Translating the WHO Framework Convention on Tobacco Control (FCTC): Can We Use Tobacco Control as a Model for Other Non-Communicable Disease Control?' (2011) 125 Public Health 847; Jonathan Liberman, 'Alternative Legal Strategies for Alcohol Control: Not a Framework Convention - At Least Not Right Now' (2013) 108 Addiction 459; Allyn L Taylor and Ibadat S Dhillon, 'An International Legal Strategy for Alcohol Control: Not a Framework Convention - At Least Not Yet' (2013) 108 Addiction 450. 
In this regard, the first question that we should ask is: how can we ensure that, while recognising that evidence-based instruments enshrine the global standards for NCD prevention regulation, we are not conveying the message that what is not recommended by these instruments is not evidence-based? In Philip Morris, the absence of a specific reference to the SPR in the FCTC guidelines was stressed by the Claimants, and eventually shared by the arbitrator Gary Born in a dissenting opinion. Gary Born underlined the fact that the guidelines do not mention the SPR despite the detailed list of regulatory measures they provide, thus substantially arguing that, if the SPR were really a reasonable measure, they would be mentioned in the guidelines. ${ }^{111}$

In order to prevent this argument from being repeated and shared by future adjudicators, States should be particularly careful in including all the possible measures that are considered effective when drafting any evidencebased international instrument. Moreover, it is vital to clarify that the lists in these instruments should not be considered exhaustive. The menu of policy options of the WHO Global Action Plan on NCDs, in this respect, seems to offer the best approach, as it clarifies that the list it provides 'is not exhaustive but is intended to provide information and guidance on effectiveness and costeffectiveness of interventions based on current evidence.'112

This clarification, however, is only a partial solution. The experience with the SPR in Philip Morris raises a more profound question: how can we ensure that, by recommending a global standard, we are not preventing States to experiment with innovative solutions? The SPR was an innovative measure adopted by Uruguay to respond to marketing strategies of the tobacco industry that it observed in its national context, and as such it could have hardly been recommended by an international instrument. The FCTC, and more generally the WHO Global Action Plan for NCDs, have already been criticised for not including alternative approaches to reduce lifestyle risks. ${ }^{113}$ Evidence-based instruments are necessarily conservative, as they are by definition limited to what has already been experimented. However, these measures may not be the best ones, and we should keep looking for better alternatives. Although evidence-based international instruments can provide useful guidance and

\footnotetext{
111 Philip Morris $v$ Uruguay, ICSID Case No ARB/10/7, Concurring and Dissenting Opinion (8 July 2016) paras 99-100, 124-25.

112 WHO (n 15) Annex 3.

113 Rebecca L Haffajee and M Gregg Bloche, 'The FCTC and the Psychology of Tobacco Control' (2010) 5 Asian Journal of WTO \& International Health Law and Policy 87; Collins O Airhihenbuwa, Chandra L Ford and Juliet I Iwelunmor, 'Why Culture Matters in Health Interventions: Lessons from HIV/AIDS Stigma and NCDs' (2014) 41 Health Education \& Behavior 78 .
} 
support in litigation, international instruments such as the WHO Global Action Plan for NCDs should also encourage regulators to spur and support innovation.

Additionally, but related to the last point, we should ask: how can we ensure that by recommending a global standard we are not curtailing the possibility for a State to adopt additional regulations tailored to its social and cultural circumstances? This question did not expressly arise in Philip Morris, but it did in the WTO Clove Cigarettes dispute. In that case, the United States (US) was asked to justify why its ban on flavoured cigarettes excluded menthol cigarettes while the FCTC Partial Guidelines to Articles 9 and 10 recommended banning them. ${ }^{114}$ Among other arguments, the US maintained that the exclusion was done not to protect its national industry, but to take into account national circumstances, and precisely the fact that many people in the US were addicted to menthol cigarettes. ${ }^{115}$ If the US were to ban menthol cigarettes, the addicted people would have to look for a replacement or for therapy, overwhelming the national health system. The panel did not analyse this argument, ${ }^{116}$ but it remains a crucial objection to the adoption of the recommendations contained in international instruments.

It is fundamental that any NCD prevention regulation measure is adapted to the local culture, and takes into account geographical and social considerations (including, for example, whether a particular product is mostly consumed by an ethnic group or by a specific socio-economic segment of the population). Although this need is stressed in the academic literature, ${ }^{117}$ it is only moderately recognised in the FCTC ${ }^{118}$ and in the WHO Global Action Plan on NCDs. ${ }^{119}$ This caution may be explained by the fact that cultural relativism is a contentious issue in human rights and in international law more broadly. ${ }^{120}$ References to culture and national contexts may be seen as inviting States to adopt lower standards in the prevention of NCDs. However, the two

114 WTO, United States - Measures Affecting the Production and Sale of Clove Cigarettes, Report of the Panel (2 September 2011) WT/DS406/R.

115 WTO, United States - Measure Affecting the Production and Sale of Clove Cigarettes, US Answers to the Panel's First Set of Questions (6 January 2011) para 49-54<https://ustr .gov/node/1457> accessed 22 March 2019.

116 United States - Clove Cigarettes (n 114) para 7.229.

117 David V McQueen, Global Handbook on Noncommunicable Diseases and Health Promotion (Springer Science \& Business Media 2013) 327-31; Ross Barnett and others, Smoking Geographies: Space, Place and Tobacco (John Wiley \& Sons 2017).

118 FCTC (n 6) art 4(3).

119 WHO (n 15) 13.

120 William J Talbott, Which Rights Should Be Universal? (OUP 2007); Reza Afshari, Human Rights in Iran: The Abuse of Cultural Relativism (University of Pennsylvania Press 2011). 
concepts should not be confused. Using cultural and local factors to determine the level of protection is different from using cultural and local factors to determine how to achieve a specific level of protection.

Finally, the last question we should ask is: how can we ensure that the evidence we enshrine in evidence-based instruments is not outdated? Evidence-based instruments should be periodically updated, so that to reflect the developments in policy-making and evidence. Unfortunately, however, the update of the guidelines is not in sight for the FCTC.

\subsection{Recognising the Relevance to Instruments such as the FCTC, the Guidelines, and the Amicus Curiae Briefs in the Evidentiary Assessment of International Disputes}

As Sub-Section 4.2 has described, the Tribunal in Philip Morris relied on the FCTC and on the guidelines for its evidentiary assessment, as well as on the interpretation of these instruments presented in the WHO/FCTC and PAHO briefs. This approach raises several questions: what is the added value that the FCTC and the guidelines (or any other similar instrument) have vis-à-vis reviews of scientific studies in a dispute? What was the added value that the WHO/FCTC and PAHO briefs really brought to the case?

The FCTC and its guidelines were not conceived as a defence instrument in litigation. However, they can be useful, for two main reasons. First, compared to reviews of scientific studies, the FCTC and the guidelines are clearer and more concise. They are already drafted for policy discussions, and to be understood by policy people coming from any of the FCTC Parties and with any background. For arbitrators facing the daunting task of making decisions based on thousands of pages of submissions, and almost a thousand exhibits, this is definitely a great advantage.

Second, the FCTC and the guidelines enjoy more legitimacy and authority than any individual expert opinion or review. As already noted, they have been adopted following an evidence-based process supported first by the WHO (for the negotiations of the FCTC), and by the FCTC Secretariat (which now supports the process of negotiations of the guidelines). Moreover, and very importantly for international lawyers, both the FCTC and the guidelines have been adopted by 181 Parties, representing the vast majority of the international community. For this reason, some authors have even gone as far as proposing that they are considered proof of an emerging opinion juris. ${ }^{121}$

However, at this point, one additional question may arise. If the FCTC and the guidelines are such useful and authoritative instruments, then why did the

121 Vadi (n 47). 
tribunal in Philip Morris mostly quote the interpretation given by the two amici curiae briefs of their provisions, in lieu of directly quoting the FCTC and the guidelines? Probably, the strength of the two briefs lies in the fact that they provided an even more effective synthesis of the relevant provisions, along with contextual information. The fact that they came from the WHO, FCTC and PAHO Secretariats gave them legitimacy. Moreover, as Sub-Section 4.2 has shown, that Uruguay did not make the best use of the FCTC and the guidelines in its submissions, especially to justify the SPR.

Uruguay seems to have learnt and adapted its strategy only after the WHO/ FCTC and PAHO briefs were submitted. Nonetheless, relying on the amici curiae briefs to provide the best interpretation and contextual explanation of the FCTC and the guidelines worked for Uruguay, but cannot be a longterm strategy. As remarked above, we cannot count on the WHO and FCTC Secretariats and regional offices to always be able and willing to intervene in any possible future dispute. Moreover, as recently argued by Alvarez, the use of the amici curiae briefs as evidence by the Philip Morris $v$ Uruguay raises questions as to why this type of 'expert opinion' is even allowed and is not subject to cross-examination. ${ }^{122}$

In possible future disputes, we should hope that the respondents learn from this case and present the best arguments on the relevance of the evidencebased instruments in their own submissions. Moreover, it is vital that they are very well prepared and equipped to defend the evidentiary relevance of these instruments. As Sub-Section 3.2 has shown, in Philip Morris the Claimants have failed to meaningfully challenge the relevance of the FCTC and the Guidelines as evidence. This point was remarked by the Tribunal, which, stating that the FCTC was a point of reference to determine the reasonableness of the measures, noted that 'in the end the Claimants did not suggest otherwise'.123 Whether the Claimants' choice was the result of a strategy, or the underestimation of their importance, we cannot expect the claimants to keep the same line in future cases.

These arguments show that it is critical not only to develop evidence-based instruments, but also to be very well prepared to present and defend their relevance to the evidentiary assessment. This requires not only great lawyers, but also great experts in public health able to convey key messages to nonspecialists. For these reasons, it is essential that the drafting processes of these instruments are always followed by capacity building for the governments of

\footnotetext{
122 Alvarez (n 4).

123 Philip Morris v Uruguay, Award (n 19) para 401.
} 
low- and middle-income States. It is not enough to draft the instruments if we do not train governments on how to best use them.

Finally, this dispute may also give us some food for thought on how to improve the process of drafting international evidence-based instruments so that they are even more suited for the purpose of acting as defence tools in litigation. The FCTC guidelines have the potential to be a great defence tool, but they suffer from some shortcomings. As noted above, in Philip Morris the two amici curiae briefs probably provided a more effective synthesis of the existing evidence than the FCTC and the guidelines. For international evidence-based instruments to be as effective as those briefs, one suggestion would be to make sure that they are always divided into two parts: first, the synthesis of existing evidence (e.g. 'bigger health warnings are proven to be more effective'), and second the recommended policy measures (e.g. health warnings should aim to cover 'as much of the principal display areas as possible').

\subsection{The Importance of Participating in the FCTC Process}

The FCTC is an important treaty because it has convinced 181 Parties to sign up for it and commit to taking action in order to reduce tobacco consumption and exposure to tobacco smoking. The implementation of the treaty requires a continuing effort, and not all countries are implementing tobacco control measures at the same pace. ${ }^{124}$ Nonetheless, even without taking into accounts its effects, the FCTC has been a milestone of the tobacco control movement because of the process that it triggered. Several authors and first-hand participants have highlighted how the process of negotiation of the FCTC had already contributed to raising awareness of the tobacco epidemic, as well as to sharing knowledge and expertise across countries. ${ }^{125}$ The development of the guidelines, as well as the bi-yearly meetings of the Conference of the Parties (COP), are keeping the process ongoing.

It is welcome that the Tribunal in Philip Morris $v$ Uruguay understood the importance of this process. As described in Sub-Section 4.1, the Tribunal ruled that participation in the FCTC process meant that Uruguay had acquired the necessary knowledge and expertise to adopt tobacco control measures. In particular, the Tribunal affirmed that:

124 FCTC, '2018 Global Progress Report on Implementation of the WHO Framework Convention on Tobacco Control' <www.who.int/fctc/reporting/WHO-FCTC-2018_global _progress_report.pdf $>$ accessed 11 January 2019.

125 Derek Yach, 'The Origins, Development, Effects, and Future of the WHO Framework Convention on Tobacco Control: A Personal Perspective' (2014) 383 The Lancet 1771; Heather Wipfli, The Global War on Tobacco: Mapping the World's First Public Health Treaty (JHU Press 2015). 
[f]or a country with limited technical and economic resources, such as Uruguay, adhesion to the FCTC and involvement in the process of scientific and technical cooperation and reporting and of exchange of information represented an important if not indispensable means for acquiring the scientific knowledge and market experience needed for the proper implementation of its obligations under the FCTC and for ensuring the fulfilment of its tobacco control policy ${ }^{126}$

This is a very critical and relevant recognition of the role of the law-making process of the FCTC, especially for low- and middle-income countries who have fewer resources to carry out long and comprehensive domestic reviews of evidence. Relying on the participation in an international process is a quite easy and inexpensive way for these countries to defend NCD prevention regulation in possible future investment cases. We cannot predict whether the Philip Morris Tribunal's ruling on this point will be followed by future arbitral tribunals. However, low- and middle-income countries should feel even more encouraged to participate in international fora where technical expertise on NCD prevention regulation is discussed, and national experiences are shared.

Nonetheless, participating in these international processes is not enough: it is also imperative to make arbitrators understand the importance thereof. In Philip Morris the importance of the FCTC process was not highlighted in Uruguay's defence. Significantly, the Tribunal extensively quoted the WHO/ FCTC submission to support its ruling on this point. ${ }^{127}$ Learning from this experience, other countries should not.

\section{Conclusions}

Philip Morris represents an important case for international investment arbitration. It was a high-profile case in which the arbitrators chose to pay great deference to the sovereign choices of the State. This move can contribute to reinforcing the perception of legitimacy of the whole system in a moment when it is put into doubt. ${ }^{128}$

At the same time, it is an even more significant case for NCD prevention regulation. Not only was it the first challenged NCD prevention regulation measure in an investment forum, but the completeness of the available documents

126 Philip Morris v Uruguay, Award (n 19) para 395.

127 ibid paras 394, 396.

128 Vadi and Gruszczynski (n 103). 
allows us to have a complete grasp of the case. States willing to enact more NCD prevention measures should attentively read this case to learn how important it is to develop international evidence-based instruments, and to prepare their defence in case an international investment dispute is brought against them. This article has tried to support this effort, discussing how evidence-based international instruments such as the FCTC and its guidelines can be best drafted and used.

We cannot know if and how many international investment disputes will be brought against NCD prevention measures. Tobacco control is undoubtedly a very conflictual area where legal challenges are likely. The tobacco industry's attempts to deceptively lobby against tobacco control measures have been exposed, ${ }^{129}$ and the industry is now prevented from participating in policy discussions. ${ }^{130}$ The same is not true for the food or alcohol industries, although some authors have started to caution policy-makers. ${ }^{131}$ Should the approach toward the food and alcohol industry change, many more disputes may be brought. In that case, States willing to strengthen their NCD prevention regulation framework would surely be better off in participating in the relevant international fora where technical expertise and evidence is shared, and learn how to make the best of this participation for their defence.

129 Stanton A Glantz and others, The Cigarette Papers (University of California Press 1998); Mamudu, Hammond and Glantz (n 21); Naomi Oreskes and Erik M Conway, Merchants of Doubt: How a Handful of Scientists Obscured the Truth on Issues from Tobacco Smoke to Global Warming (reprint edition, Bloomsbury Press 2011); Robert N Proctor, Golden Holocaust: Origins of the Cigarette Catastrophe and the Case for Abolition (University of California Press 2012).

$130 \quad$ FCTC (n 6) art 5(3).

131 Kelly D Brownell and Kenneth E Warner, 'The Perils of Ignoring History: Big Tobacco Played Dirty and Millions Died - How Similar Is Big Food?' (2009) 87 The Milbank Quarterly 259. 